\title{
AUXIN SIGNAL TRANSDUCTION INTO A QUANTITATIVE CHANGE IN NATURAL AUXIN POLAR TRANSPORT IN PINE CAMBIUM
}

\author{
TOMASZ J. WODZICKI, ALINA B. WODZICKI AND JACEK ADAMCZYK \\ Department of Forest Botany, Agricultural University of Warsaw (SGGW) \\ 26/30 Rakowiecka St., 02-528 Warsaw, Poland
}

(Received: April 30, 1999. Accepted: June 20, 1999)

\begin{abstract}
Results of experiments performed with 6-mm high stem sections of Pinus sylvestris L. confirmed the hypothesis that the fusiform cells of the cambial region respond to the arrival of indole-3-acetic-acid (IAA) at the signalling concentration in the apoplastic space around their apical ends by increasing the basipetal efflux of endogenous natural auxin. Thus, the auxin signal propagation along the stem cambial region could be a chain of reactions between the axially neighbouring cells, each capable of responding and contributing to the change of auxin concentration in the apoplast which requires only transduction of the foreign auxin signal by each of the cells to increase the basipetal efflux of their own endogenous auxin. The rate of auxin signal propagation in this system is not limited by the rate of auxin molecular transport, and if it functions in conjunction with feedback inhibition, it may produce oscillations of the auxin basipetal efflux generating supracellular auxin waves. Inhibitors of the proteinaceous auxin efflux carrier associated with the plasmalemma (NPA and TIBA), although reducing total basipetal transport of the natural auxin, did not prevent the stimulated additional efflux of this phytohormone. The studied auxin-signal transduction processes seem to be intracellular but not mediated by the Ca-calmodulin complex. The natural auxin basipetal efflux increased significantly within $45 \mathrm{~min}$ following the period when it had been strongly reduced by successive collections to agar receivers replaced several times at the basal ends of 6-mm high stem sections in which the intact fusiform cells of the cambial region in about $90 \%$ are arranged in only one axial row. Such exhaustion of the cellular reserve of auxin did not prevent the additional auxin basipetal efflux stimulated by the IAA apical treatment. The results may suggest an effect of the auxin signal upon the supply of newly-synthesised auxin directly to the system responsible for its basipetal efflux.
\end{abstract}

KEY WORDS: auxin signal, polar transport, cambium, Pinus sylvestris.

\section{INTRODUCTION}

Progress in molecular biology of the last decade and availability of methods and/or laboratory facilities stimulated plant physiologists to concentrate upon identification and control of the genetic programs or genes associated with morphogenesis and their first expression at the cellular level. To produce the functional pattern of the plant body, the genetic programs are induced by the epigenetic systems generating the morphogenetic fields which coordinate development over large areas exceeding often hundreds or thousands (and even millions) times the dimensions of cells within the differentiating multicellular structures. The role of the phytohormones, and especially auxin with its specific polar transport, in formation of such morphogenetic fields is usually accepted but none of the theories so far proposed has been able to explain how they originate and are translated to the morphological pattern. Zajączkowski and Wodzicki (1978); Zajączkowski et al. (1983), Wodzicki and Zajączkowski (1989) proposed that the morphogenetic field is based upon information specified when the waves of auxin move in the meristematic cambial region of trees. The proposed morphogenetic mechanism refers to the periodic changes of polarity expression in the successive cam- bial cell series along the stem axis measured as differences in the amounts of the natural auxin basipetal efflux (Wodzicki et al. 1984). The amplitude of these changes can be modified by phytohormones, e.g., increased by the apical application of IAA whose effect propagates several times faster than the molecular polar transport of auxin (Wodzicki et al. 1979; Wodzicki and Wodzicki 1981). The origin of phase-shift of the supracellular auxin waves requires coupling in the processes responsible for periodic changes in the amount of basipetal auxin efflux between the successive cells of the stem cambial region.

This paper refers to the hypothetical mechanism for auxin signal transduction into the change of amount of the auxin basipetal efflux from the responding cells (Wodzicki 1993). The suggested auxin signal transduction is based on the assumption that increase of auxin concentration acting from outside the target cell stimulates in this cell: 1) the liberation of auxin from the cytosolic pool (probably from its conjugates) directly into the basipetal efflux, 2) the synthesis of new auxin which restores the cytosolic reserve which is in turn associated with feedback inhibition of increased auxin efflux. The results of experimental testing of some aspects of this hypothesis are presented below. The proposed mechanism of local 
amplification of polar auxin transport could be a possible way of explaining how the auxin waves originate and are propagated, forming the morphogenetic field in the stem cambium of trees.

\section{MATERIAL AND METHODS}

All experiments were done with small sections of pine (Pinus sylvestris L.) stem cambial region resectioned in the laboratory from larger stem blocks obtained a few hours earlier in the forest. The sections $6-\mathrm{mm}$ high in axial, $2-3 \mathrm{~mm}$ in radial and 6,22 or $24 \mathrm{~mm}$ wide in the horizontal direction of stem circumference were composed of: 1) periderm from which the outer bark was removed, 2) secondary phloem, 3) meristematic cambial zone, 4) differentiating secondary xylem, 5) 2-3 recent annual rings of wood. For investigation of the natural pine auxin which is indole-3-acetic acid (Wodzicki 1968, Alden and Eliasson, 1970; Sandberg et al. 1981), these 6-mm high stem sections were used immediately after recutting from the larger stem blocks. Their 6 or $22-\mathrm{mm}$ length and about $3 \mathrm{~mm}$ thickness were suitable for application either of two $(2 \times 2 \times 2 \mathrm{~mm})$ blocks or $(20 \times 2 \times 2 \mathrm{~mm})$ strip of agar used respectively as the receivers and donors for auxin diffusing from, or into the transversely cut tissues. These blocks or strips of $1 \%$ aqueous DIFCO bacteriological grade agar were applied at the apical and basal ends of the tissue sections at the position of the cambial zone and differentiating tissues. After a predetermined period of diffusion, the agar receiver or donor blocks were either subjected immediately to auxin measurements or strips were cut to 10 cubes $(2 \times 2 \times 2 \mathrm{~mm})$ for bioassay (each of these cubes was applied to a single oat coleoptile section). The method of biological identification and quantitative measurement of the auxin diffused into the agar was a modified version of the procedure of Funke (1939) based upon the oat coleoptile curvature test originally developed by Went (Went and Thimann 1937). The modifications as described by Alina B. Wodzicki et al. (1997) were critical for reducing the variability of the method and rendered it highly reproducible for the quantitative measurement of picogram amounts of auxin. Mean results of the bioassays presented in this paper refer to the amounts of natural auxin collected from the cambial region corresponding to 2 $\mathrm{mm}$ wide transverse section in the direction of stem circumference at chest height ( $1.3 \mathrm{~m}$ above the ground) of forest grown adult pine trees. Each experiment in which the natural auxin efflux was tested was done with a different tree sampled in Spring during the period of cambial meristematic activity. Results of the bioassays, each comprising 10 oat coleoptile sections in which growth-response was measured in degrees of curvature, were recalculated to picograms of authentic IAA using the standard growth-stimulation curves obtained in this laboratory, while the control series testing the synthetic IAA were included. Earlier HPLC studies followed by GS-MS SIM identification confirmed that all the auxin collected by diffusion to agar from the $P$. sylvestris stem cambial region and tested with bioassays was natural indole-3acetic acid (Wodzicki et al. 1987).

Radioactivity in the agar donors or receivers $(\mathrm{cpm})$ was measured using the 1209 Racbeta LKB, Wallac scintillation counter.

The chemicals were obtained from:

IAA - [Indole-3-acetic acid], Aldrich-Chemie, Germany.

NPA - [naphtalenephtalamic acid], courtesy gift of professor Reiner Hertel, Freiburg, Germany.
W-7 - [n-(6-aminohexyl)-5-chloro-1-naphtalene sulfonamide hydrochloride], Sigma Chemical Co. USA.

${ }^{3} \mathrm{H}-\mathrm{IAA}-\left\{3-\left[5(\mathrm{n})-{ }^{3} \mathrm{H}\right]\right.$ indole-3-acetic acid, specific activity $999 \mathrm{Gbq} / \mathrm{mmol}, 5.66 \mathrm{Gbq} / \mathrm{mg}$, Amersham, USA.

\section{RESULTS}

The IAA signal induces an increased basipetal efflux of natural auxin

Indole-3-acetic acid at a concentration of $0.57 \mu \mathrm{M}(0.1$ ppm) was applied in agar strips to the apical end of the 6- $\mathrm{mm}$ stem sections opposite the cambial zone (as shown in Fig. 1 A), for $15,30,45$ and 60 minutes. The substances diffusing into the pure agar receiver strips were collected from the basal ends of the same stem sections and during the same periods. Results of the biological testing of the receiver strips showed that the increase of IAA concentration in the apoplast at the apical end of the cambial tissue sections stimulates basipetal efflux of auxin (Fig. 1 C). The minimal time for this stimulation is between 15 and 30 minutes. Analogous application of the IAA donors at basal ends of the stem sections did not induce additional amounts of auxin diffusion into the apically applied receiver agar strips (Fig. I B). The dynamics of auxin efflux stimulated by the apical IAA application seems to stabilize between 30 and 45 minutes and then increase again during the subsequent $15 \mathrm{~min}$ (Fig. 1 D). The additional auxin efflux was not due to basipetal translocation of the synthetic IAA applied to the apical end of the stem sections, as shown by tracing the movement of tritium-labelled IAA (Table 1). In these control series, the concentration of 0.57 $\mu \mathrm{M}$ IAA given in the apically applied agar donors increased there to $0.655 \mu \mathrm{M}$ when the $3-\left[5(\mathrm{n})-{ }^{3} \mathrm{H}\right] \mathrm{IAA}$ was added but no radioactive substances were found translocated during at least $60 \mathrm{~min}$ into the agar receiver blocks attached to the basal ends of stem sections.

TABLE 1. Absorption of ${ }^{3} \mathrm{H}-\mathrm{IAA}$ from the agar blocks (donors) applied at apical end, and its basipetal transport through 6-mm high section of the pine stem cambial region to agar blocks (receivers). Averages of 8 stem sections \pm standard error.

\begin{tabular}{|c|c|c|c|c|c|}
\hline \multirow{2}{*}{$\begin{array}{l}\text { Agar } \\
\text { blocks }\end{array}$} & \multicolumn{5}{|c|}{ Radioactivity $[\mathrm{cpm}]$ after minutes } \\
\hline & 0 & 15 & 30 & 45 & 60 \\
\hline Apical & $\begin{array}{c}102266 \\
\pm 4587\end{array}$ & $\begin{array}{r}52971 \\
\pm 1728\end{array}$ & $\begin{array}{l}23683 \\
\pm 3310\end{array}$ & $\begin{array}{l}28875 \\
\pm 2046\end{array}$ & $\begin{array}{l}29898 \\
\pm \quad 1046\end{array}$ \\
\hline Basal & 0 & $\begin{array}{c}12 \\
\pm 5.2\end{array}$ & $\begin{aligned} & 36 \\
\pm & 25.0\end{aligned}$ & $\begin{array}{c}13 \\
\pm 2.9\end{array}$ & $\begin{array}{r}12 \\
\pm 2.5\end{array}$ \\
\hline
\end{tabular}

\section{Auxin apical treatment and exogenous IAA polar transport}

Sixteen pine stem tissue squares $(24 \times 24 \times 3 \mathrm{~mm})$ comprising the cambial region were recut from the larger stem blocks and divided to two experimental variants, 8 replicates each. Agar strips applied to the apical ends of the 8 samples of the 1st variant contained $0.57 \mu \mathrm{M}$ IAA. Pure agar strips were applied to the apical end of the 8 samples of the 2 nd variant, as well as to the basal ends of all 16 samples. After 90 min the square-samples were recut as shown in Fig. 2 B. The upper 6$\mathrm{mm}$ and the lower $12-\mathrm{mm}$ segments of the square-samples were discarded. Only the 6-mm wide tissue-strips, second from the apical edge of each sample were taken for further investigation and cut into four $6 \times 6 \times 3 \mathrm{~mm}$ stem sections. To 


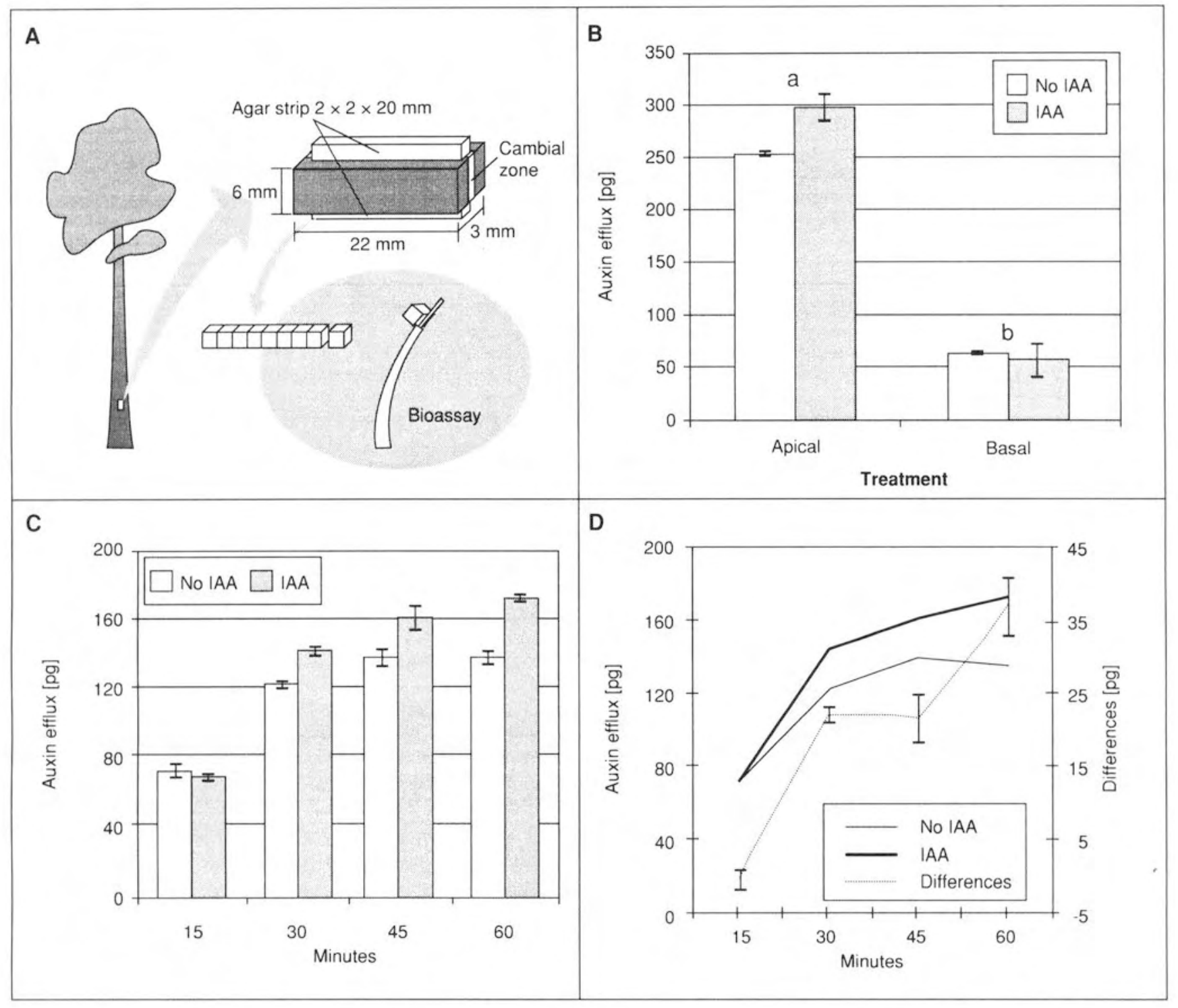

Fig. 1. Effect of the apical application of IAA $(0.57 \mu \mathrm{M})$ upon basipetal efflux of the natural auxin from the cambial region of $6 \times 22 \times 3 \mathrm{~mm}$ sections of the pine stem. A - the method of testing the auxin efflux; B - stimulation of the auxin efflux takes place only if synthetic IAA is applied to the apical end of stem section, [agar donors applied at the apical (a) or basal (b) end]; C - effect of the apical application of IAA for 15, 30, 45 or $60 \mathrm{~min}$; D - dynamics of the auxin efflux stimulation. Mean results of at least two tests each of 10 Avena coleoptiles. Vertical bars - SE.

the apical ends of all 64 of these sections of the stem tissue, ${ }^{3} \mathrm{H}-\mathrm{IAA}$ in two $2 \times 2 \times 2 \mathrm{~mm}$ agar blocks was applied to provide an average $82250.6 \mathrm{cpm}$ per section. All radioactive donors and all basal receivers (two $2 \times 2 \times 2 \mathrm{~mm}$ pure agar blocks applied at each of the tissue sections) were collected after $90 \mathrm{~min}$ and replaced with fresh blocks of pure agar. The basal receivers of series I ( 8 replicate sections) were now replaced every $30 \mathrm{~min}$ over a $3 \mathrm{hr}$. period. The receivers (both apical and basal) were collected only once after: $60,180,360$ min from the successive tissue-sections of series II, III and IV, respectively. To the sections of series IV fresh receiverblocks of pure agar were applied also overnight $(12 \mathrm{~h})$ and once more during following day $(10 \mathrm{~h})$.

As much as 70-90\% tritium-labelled IAA from the apically applied agar blocks was absorbed during $90 \mathrm{~min}$ by the stem tissue sections (Table 2). The differences in the rate of basipetal transport of the labelled auxin between the series pretreated with unlabelled IAA and the controls were not significant (Fig. 2 A and Fig. 3). The measurable radioactivity in the basal receivers was recorded no earlier than $120-150 \mathrm{~min}$ after apical application of ${ }^{3} \mathrm{H}$-IAA or 30 to $60 \mathrm{~min}$ after removal of the donors and it was not more than 0.9 percent of the total absorbed within the tissue even 4.5 hours later. The basipetal efflux of radioactive auxin (or its tritium-labelled derivative substances) when measured the next day (12 or $12+10 \mathrm{~h}$ later) was drastically reduced and there is no proof that it was still due to the active polar transport.

In the two following experiments (performed on different days with different trees) ${ }^{3} \mathrm{H}$-IAA was supplied to the apical ends of $6 \times 6 \times 3 \mathrm{~mm}$ stem tissue sections for $60 \mathrm{~min}$ and then replaced for next $45 \mathrm{~min}$ with the donors containing either $0.57 \mu \mathrm{M}$ unlabelled IAA or pure agar. These donors were replaced after $45 \mathrm{~min}$ with pure agar blocks. About 70$80 \%$ of the labelled auxin (equivalent to ca $60000 \mathrm{cpm}$ per donor) was taken into the tissue sections during the 60-min period. Pure agar blocks (the receivers) were applied and replaced every $45 \mathrm{~min}$ at the basal ends of all investigated stem tissue sections and their radioactivity was measured.

No basipetal transport of radioactive substances to the receivers was detected in either series of the two experiments 
(Fig. $4 \mathrm{~A}$ and $\mathrm{B}$ ) after the $60 \mathrm{~min}$ period of the ${ }^{3} \mathrm{H}$-IAA donors contact with the stem sections. The first traces of radioactivity were measured in all cases after $45 \mathrm{~min}$ following this period ( $105 \mathrm{~min}$ since the time the radioactive auxin has been applied). In the first experiment, small additional basipetal transport of the labelled IAA may be seen in the auxin stimulated series $45 \mathrm{~min}$ after it was applied (Fig. $4 \mathrm{~A}$ ). This continued later but the differences after an additional 90 and

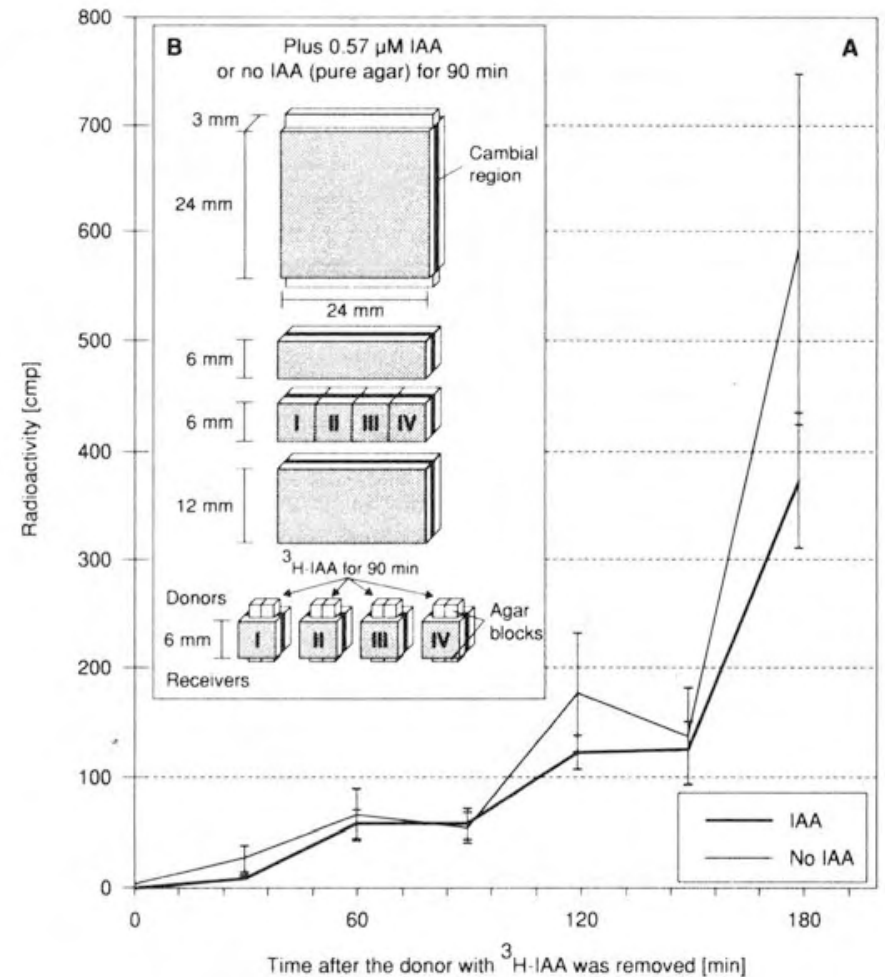

Fig. 2. A - Basipetal transport of ${ }^{3} \mathrm{H}$-IAA applied for $90 \mathrm{~min}$ to the apical ends of $6 \times 6 \times 3 \mathrm{~mm}$ pine stem cambial sections obtained by division of the larger stem tissue squares $(24 \times 24 \times 3 \mathrm{~mm})$ to whose apical edges either unlabelled IAA $(0.57 \mu \mathrm{M})$ or pure agar strips had been previously applied for $90 \mathrm{~min}$. The radioactivity was measured in the basal agar blocks (receivers) exchanged every $30 \mathrm{~min}$ during 3 hours following the $90 \mathrm{~min}{ }^{3} \mathrm{H}$-IAA treatment (after the donors were removed) (series I). Averages of 8 replicate tissue units. B - Method of the pine stem sectioning for investigation of ${ }^{3} \mathrm{H}$-IAA basipetal movement in the pine stem cambial square pre-treated with unlabelled IAA.

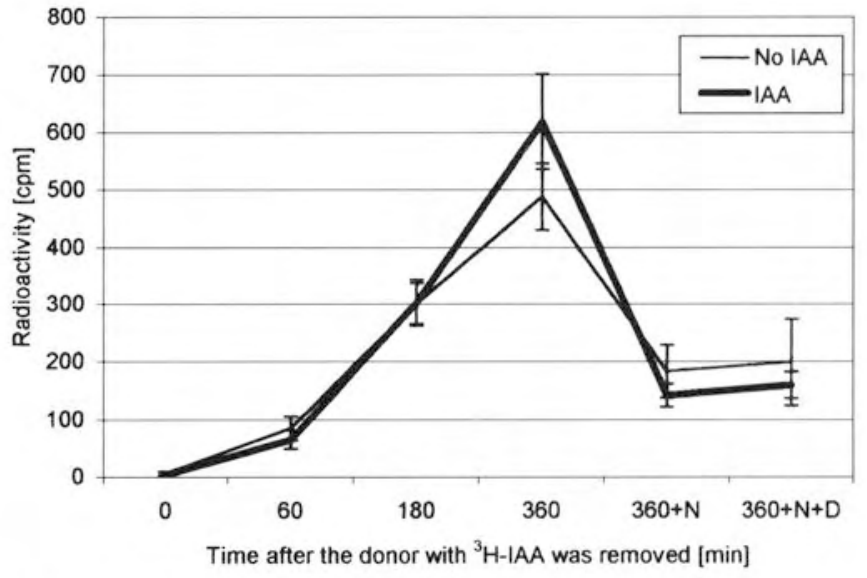

Fig. 3. Basipetal transport of ${ }^{3} \mathrm{H}-\mathrm{IAA}$ applied for $90 \mathrm{~min}$ to the apical ends of 6-mm high stem sections. The radioactivity was measured in the basal agar blocks (receivers) collected only once: 60,180 or $360 \mathrm{~min}$ (series II, III, IV respectively), after the radioactive donors were replaced with pure agar blocks, as described in Fig. $2 \mathrm{~B}$. In series IV the receivers collected after $360 \mathrm{~min}$ were replaced twice after $12(\mathrm{~N})$ and 10 (D) hours respectively. Averages of 8 replicate $6 \mathrm{~mm}$ high stem-sections except for the time 0 (the time of removal of ${ }^{3} \mathrm{H}$-IAA donors) which represents results obtained for receivers collected from 32 sections.

$135 \mathrm{~min}$ appeared to be insignificant. These differences between the two series were not confirmed in the second experiment, and only at the last two 45-min periods did the radioactive IAA transport appear to be slightly higher in the stem sections whose apical ends were treated earlier with unlabeled IAA (Fig. 4 B). The radioactivity of the basal receivers which always consisted of two agar blocks was very small even at highest rate. It was not more then $0.08-0.3 \%$ of the total radioactivity of ${ }^{3} \mathrm{H}$-IAA taken by the tissue at any of the 45 min periods, as calculated for the second experiment. No relation was found between the differences in amounts of the absorbed ${ }^{3} \mathrm{H}$-IAA and the basipetal transport of this auxin in any of the experiments.

Is the cell membrane auxin efflux carrier involved in the transduction of IAA signal to increased basipetal transport of the natural auxin?

The inhibitor of the cell membrane protein to which the function of auxin carrier in the process of basipetal efflux is attributed, NPA (Hertel 1987), was included at $20 \mu \mathrm{M}$ into agar blocks applied for $45 \mathrm{~min}$ as the donors of IAA to apical

TABLE 2. Uptake of ${ }^{3} \mathrm{H}$-IAA by the $6 \times 6 \times 3 \mathrm{~mm}$ pine stem sections during $90 \mathrm{~min}$ which followed the 90 -min pre-treatment of the larger tissue squares $(24 \times 24 \times 3 \mathrm{~mm})$ with $0.57 \mu \mathrm{M}$ of unlabelled IAA or pure agar strips applied at the apical edges of these stem tissue squares. Data give the average total radioactivity $(\mathrm{cpm})$ which still remained after $90 \mathrm{~min}$ in the donor agar blocks, and the percentages refer to the average $(82250.6 \mathrm{cpm})$ amounts of the radioactivity applied to the apical end of each stem-section. In each series of 8 replicate stem-sections the ${ }^{3}$ H-IAA basipetal movement was measured as follows: series I - every $30 \mathrm{~min}$ for a period of 3 hours; series II, III, IV, only once after 60 , 180,360 min respectively.

Pre-treatment for $90 \mathrm{~min}$

(followed by $90 \mathrm{~min}{ }^{3} \mathrm{H}-\mathrm{IAA}$ absorption)
Series

I II II

III

IV

\begin{tabular}{cccccc}
$\begin{array}{c}0.57 \mu \mathrm{M} \text { IAA } \\
\text { (unlabelled) }\end{array}$ & Total & $25003 \pm 6125$ & $18291 \pm 4064$ & $13215 \pm 2752$ & $11907 \pm 1564$ \\
\cline { 2 - 6 } & Percent & 69.6 & 77.7 & 83.9 & 85.5 \\
No IAA & Total & $14796 \pm 2077$ & $10500 \pm 1732$ & $9365 \pm 2041$ & $16203 \pm 3430$ \\
\cline { 2 - 6 } & Percent & 82.0 & 87.3 & 88.6 & 80.3
\end{tabular}




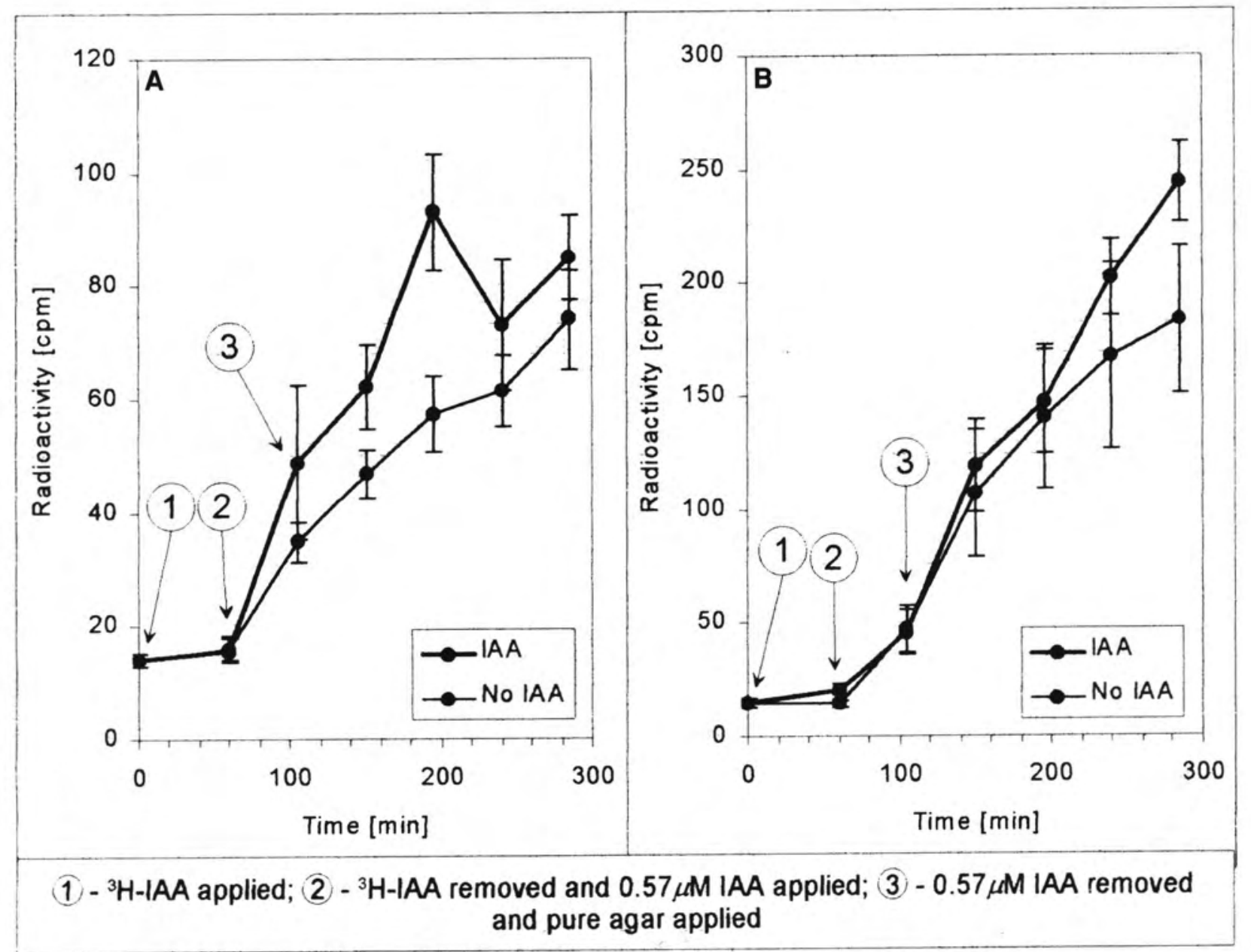

Fig. 4. Basipetal transport of ${ }^{3} \mathrm{H}$-IAA applied for $60 \mathrm{~min}$ in agar blocks (donors) at the apical end of $6 \times 6 \times 3 \mathrm{~mm}$ pine stem sections. Radioactive donors were replaced after $60 \mathrm{~min}$ with either agar blocks containing $0.57 \mu \mathrm{M}$ unlabelled IAA or pure agar blocks. After 45 min the donors were replaced with pure agar blocks. The basal receiver blocks of pure agar were collected after the 60 -min period of ${ }^{3} \mathrm{H}-\mathrm{IAA}$ treatment, and then at the end of each of five consecutive 45-min periods. Averages for the two experiments (A and B) refer to 6 and 8 stem tissue replicate sections, respectively.

ends of $6 \times 6 \times 3 \mathrm{~mm}$ stem tissue-sections. The concentration of NPA used in these experiments was determined in preliminary tests.

It is seen (Fig. $5 \mathrm{~A}$ ) that NPA significantly reduced basipetal efflux of the natural auxin from the stem cambial region of pine but not the stimulation of additional efflux due to the simultaneously applied IAA.

In next two experiments the effect of TIBA, another inhibitor of auxin polar transport associated with function of the plasmalemmal efflux carrier, was tested. This time, the inhibitors (NPA or TIBA) were included into the agar strips used as receivers for the natural auxin basipetal efflux when applied to basal ends of the 6-mm high stem sections. Rate of translocation of NPA and TIBA in stem tissues is assumed to be no more than $2.5 \mathrm{~mm}$ per hour (Thomson et al. 1973). Thus, these experiments allowed direct influence of the inhibitors upon the auxin efflux carriers if they were associated with the plasmalemma at basal ends of the long fusiform cells in the cambial region. Such localization of the auxin basipetal efflux carriers could be expected according to the results reported by Goldsmith (1977). Using bioassay as a method of determining and quantifying amounts of the natural auxin efflux, it was necessary to include also a synthetic IAA into the tested receiver strips of agar to produce the oat coleoptile growth response and overcome the growth-retarding effect of the in- hibitors upon the coleoptiles. The effects were tested at two concentrations of TIBA. It was 20 and $200 \mu \mathrm{M}$ in the two experiments, respectively.

Results (Table 3) of both experiments confirmed that the inhibition of auxin efflux carrier did not prevent the increase of basipetal efflux of natural auxin from the pine cambial region when it was induced by the increase of exogenous IAA in the apoplast associated with the apical end of fusiform cells within the 6-mm high stem sections.

Does the transduction of IAA signal to increase auxin basipetal efflux involve the system mediated by the Ca-calmodulin complex?

The effect of the Ca-calmodulin coupling inhibitor was used in experiments testing the possibility of dependence of the auxin signal transduction to increase of the basipetal auxin efflux upon the cell ionic calcium regime regulated by this system. N-(6-aminohexyl)-6-chloro-1-naphtalenesulfonamide (W-7) (Hidaka et al. 1981), at a conc. of $200 \mu \mathrm{M}$ was included into the agar donor strips $(20 \times 2 \times 2 \mathrm{~mm})$ containing (or not) $0.57 \mu \mathrm{M}$ IAA and applied for $45 \mathrm{~min}$. to the apical ends of the $22 \times 6 \times 3 \mathrm{~mm}$ stem sections. In another experiment the stem tissue sections were bathed in the W-7 solution during $1 \mathrm{~h}$ before the 45 -min inductive period. 


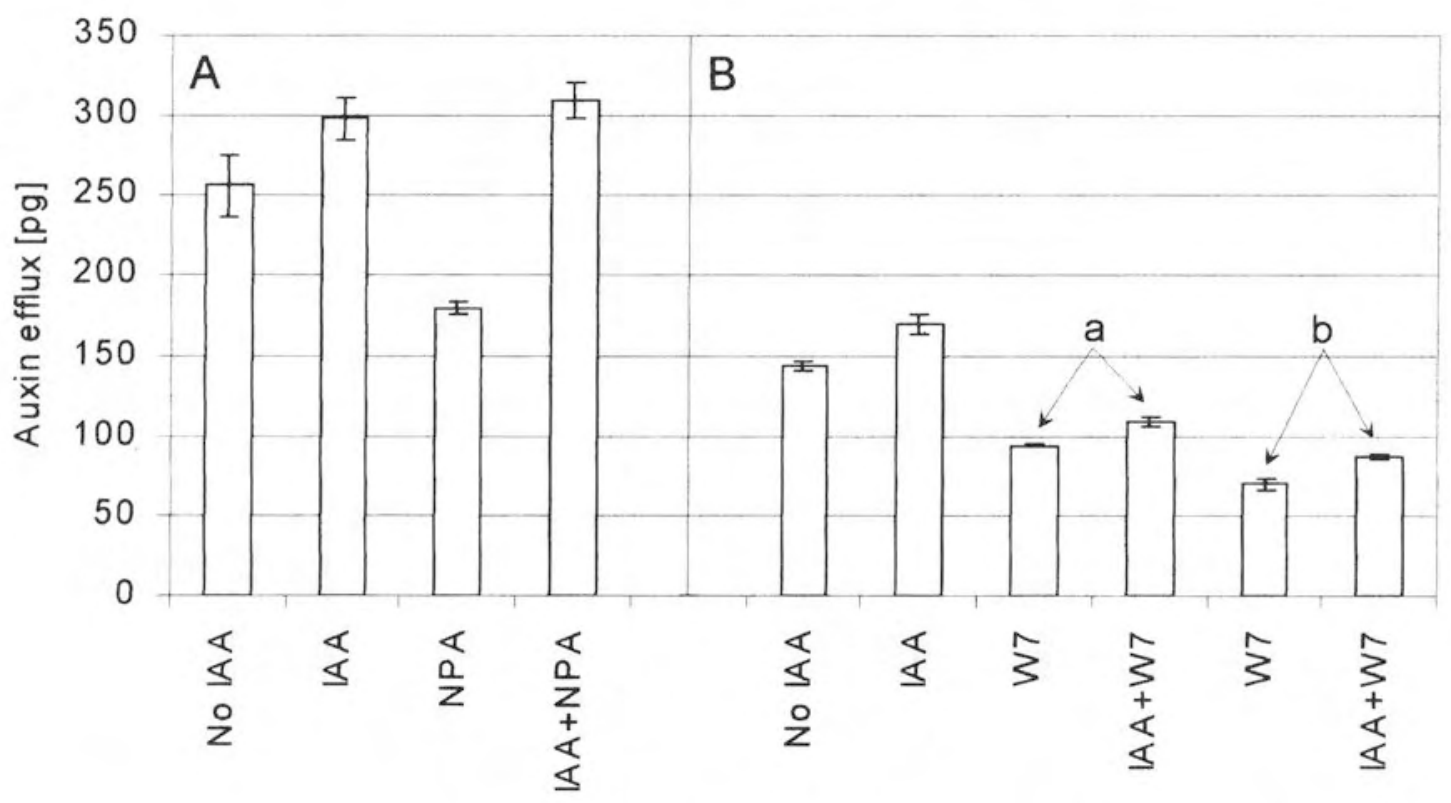

Fig. 5. Effect of inhibitors upon the natural auxin basipetal transport stimulated by the 45 -min apical application of synthetic IAA to the 6 mm high and $22 \mathrm{~mm}$ wide pine stem sections comprising the cambial region. A - effect of NPA, an inhibitor of the auxin basipetal efflux carrier; B - effect of W7, an inhibitor of the Ca-calmodulin complex. applied to the stem section apical end (a) or when the sections were bathed for $1 \mathrm{~h}$ before the apical IAA-treatment (b). Averages of 2 replicate tests.

TABLE 3. Effect of inhibitors of auxin polar transport (NPA and TIBA) included in the basal receiver blocks of agar containing $0.57 \mu \mathrm{M}$ IAA upon the stimulation of natural auxin basipetal efflux by the treatment with $0.57 \mu \mathrm{M}$ IAA applied for 45 min to the apical end of the 6 -mm stem sections. The NPA concentration in the two independent experiments, and the TIBA in the experiment 1 was $20 \mu \mathrm{M}$. TIBA concentration, in the 2 nd experiment was $200 \mu \mathrm{M}$.

0

IAA

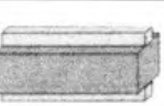

0
0

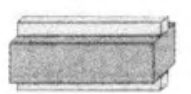

$\mathrm{IAA}+\mathrm{NPA}$
IAA

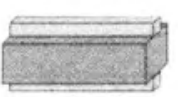

$\mathrm{IAA}+\mathrm{NPA}$
0

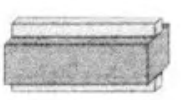

$\mathrm{IAA}+\mathrm{TIBA}$
IAA

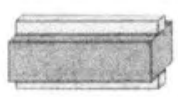

$\mathrm{IAA}+\mathrm{TIBA}$

\section{Amount of natural auxin in the basal receivers [pg]}

1st Experiment

$248 \pm 5.9$

$356 \pm 17.1$
$230 \pm 5.1$
$267 \pm 7.2$

$189 \pm 3.1$

$209 \pm 6.3$

2nd Experiment

$609 \pm 27.0$

$195 \pm 6.8$

$265 \pm 8.8$

$63 \pm 2.8$

$79 \pm 2.5$

Agar blocks (controls) before they were applied to the stem tissue sections

$\begin{array}{lc}\mathrm{IAA} & 973 \pm 43.3 \\ \mathrm{IAA}+\mathrm{NPA} & 85 \pm 2.8 \\ \mathrm{IAA}+\text { TIBA } & 172 \pm 5.8\end{array}$

Exp. 2nd

$936 \pm 40.7$

$99 \pm 3.8$

$59 \pm 1.5$
It is seen (Fig. 5 B) that W-7 significantly reduced the basipetal efflux of natural auxin from the cambial region of pine stem but not the stimulation of additional efflux produced by the apical application of IAA.

It seems unlikely that the effect of induction of basipetal efflux of auxin by apical application of IAA was mediated by the processes dependent upon the activity of $\mathrm{Ca}$-calmodulin complex. Thus, at least this part of the molecular mechanism involved in control of the cell Calcium ionic regime is not directly associated with the studied transduction of the signalling function of auxin studied herein.

\section{Cellular reserves of auxin for the IAA-induced increase of the} auxin basipetal efflux

In three consecutive experiments the effect of the $45-\mathrm{min}$ application of $0.57 \mu \mathrm{M}$ IAA to the apical end of the $6-\mathrm{mm}$ high and 22-mm wide pine stem sections was measured after the natural auxin from the basal end had been collected for 45,60 or $120 \mathrm{~min}$ which diminished the cellular reserves of the transportable form of this phytohormone. In the last experiment, the pure agar receiver strips were replaced every 15 minutes for $120 \mathrm{~min}$.

As in all other experiments the application of $0.57 \mu \mathrm{M}$ IAA to the apical end of the stem section for 45 min produced an 
TABLE 4. Effect of $45 \mathrm{~min}$ apical application of $0.57 \mu \mathrm{M}$ IAA upon the natural auxin basipetal efflux when it followed either $10 \mathrm{~min}(\mathrm{~A})$ or $10+45 \mathrm{~min}(\mathrm{C})$ the collection of natural auxin by diffusion to agar strips from the basal ends of $6 \mathrm{~mm}$ high and $22 \mathrm{~mm}$ wide pine stem sections comprising the cambial region. Series (B) was not treated with IAA. Averages of 3 replicate tests (pg. equ. of IAA).

\begin{tabular}{cccc}
\hline $\begin{array}{c}\text { Apical treatment } \\
\text { with } 0.57 \mu \mathrm{M} \text { IAA }\end{array}$ & \multicolumn{4}{c}{ Measured after minutes } \\
\cline { 2 - 4 } & 10 & 1st 45 & 2nd 45 \\
\hline (A) only 1st $45 \mathrm{~min}$ & $483 \pm 32$ & $279 \pm 12$ & - \\
\hline (B) no IAA & $511 \pm 6$ & $216 \pm 5$ & $198 \pm 3$ \\
\hline (C) only 2nd 45 min & $*$ & $225 \pm 9$ & $224 \pm 7$ \\
\hline
\end{tabular}

increase in the basipetal efflux of natural auxin from the cambial region. This IAA-induced stimulation was not prevented by the 45-min period of auxin collection at the basal end of the stem section (Table 4, compare series A and B; B and C). The total basipetal auxin efflux from series B untreated with IAA during the second period of $45 \mathrm{~min}$ remained little reduced. These results were confirmed by the second experiment in which the inductive $45-\mathrm{min}$ period of IAA treatment followed a 60 -min period during which the natural auxin had been collected from the basal end of stem tissue section (Table 5). Simultaneous measurement of the basipetal transport of ${ }^{3} \mathrm{H}$-IAA introduced into the apical donors of synthetic IAA for the last $45-\mathrm{min}$ of the experiment showed that no radioactive substances were found in the agar receivers in which the basipetal efflux of auxin was tested. The third experiment in which collection of the natural auxin at basal end of the stem sections was done 8 times for 15 min during the $120-$ min period preceding the apical 45-min IAA treatment revealed even stronger stimulation of the basipetal efflux of auxin (Table 5).

\section{DISCUSSION}

The investigated stem cambial region in P. sylvestris constitutes a nonstoryed structure of axially-aligned $2-5 \mathrm{~mm}$ long fusiform cells. In the 6-mm high stem sections about 88.5 percent of the intact fusiform cells in the cambial region are arranged only in a single axial row (Alina B.Wodzicki et al. 1997). These cells have both their proximal and distal neighbours transversely sectioned and along the investigated 22$\mathrm{mm}$ wide and $6-\mathrm{mm}$ high cambial sector there is no single axial row in which, if the cells were cut at both ends, would provide an open channel for uncontrolled flow of substances. The fusiform cells are tightly attached to each other by the middle lamella so there is no free space for other apoplastic transport except for the cell walls and the periplasmic space probably controlled by the plasmalemma of each cell. There is on average 648 fusiform cells of the cambium cut transversely along each of the two (apical and basal) edges of the 22$\mathrm{mm}$ wide stem section. Each cambial initial is associated with its fusiform derivative cells differentiating into secondary xylem or phloem arranged in the radial rows whose contribution to the basipetal transport of auxin depends upon the degree of their functional specialization (Nix and Wodzicki 1974). The cells of the meristematic zone and the radially enlarging xylem are probably the most efficient in the auxin polar transport. The stem cambial region of pine trees used in the experiments described in this paper were done during late April, May or early June (during Spring activation and activity of the cambium) and consisted of 7 to 14 fusiform cells in a radial row of cambial undifferentiated derivatives. This number precisely determined for the last three experiments presented in this paper was 12 to 14 , of still either meristematic or radially growing cells in the zone of differentiating secondary xylem.

Taking into account all what we know about the anatomical structure of the pine stem sections used in these experiments, we can assume that the applied synthetic auxin and other substances were first absorbed only by the transversely cut fusiform cells at the edges of stem sections and delivered to the plasmalemma of the apical (or in some experiments basal) part of a single layer of the intact fusiform cells before the more distant apoplastic spaces were penetrated. The agar receivers collected the natural auxin diffusing from the transversely cut cells, thus the auxin released from the broken cells and by the active efflux from basal ends of the intact fusiform cells of cambial region both contributed to the total

TABLE 5. Results of 2 independent experiments with 6-mm high and 22-mm wide pine stem sections comprising the cambial region in which the effect of 45 -min apical application of IAA $(0.57 \mu \mathrm{M})$ upon the natural auxin basipetal efflux when it followed a period of collection of the natural auxin for 60 or 120 minutes, 1st and 2 nd experiment respectively. In the Ist experiment auxin efflux was first tested after 60 minutes and in the 2 nd experiment the auxin was collected 8 times (each time for $15 \mathrm{~min}$ ) and first tested only after the last 15 min collection preceding application of IAA. Second testing of the natural auxin efflux was after the 45-min of IAA treatment. Averages of 3 replicate tests (recalculated for equivalents of stimulation by authentic IAA).

\begin{tabular}{|c|c|c|}
\hline \multirow[t]{3}{*}{$\begin{array}{l}\text { Experimental treatment } \\
\text { only during } 45 \text { min period }\end{array}$} & \multicolumn{2}{|c|}{$\begin{array}{l}\text { Results of measurements [pg] } \\
\text { after }\end{array}$} \\
\hline & & $45 \mathrm{~min}$ treatment \\
\hline & \multicolumn{2}{|c|}{1 st Experiment } \\
\hline \multirow[t]{2}{*}{$\begin{array}{c}\text { Plus } 0.57 \mu \mathrm{M} \text { IAA } \\
\text { No IAA }\end{array}$} & $\begin{array}{l}60 \text {-min preeceding lAA treatment } \\
230 \pm 2 \\
226 \pm 2\end{array}$ & $\begin{array}{l}240 \pm 4 \\
209 \pm 6\end{array}$ \\
\hline & \multicolumn{2}{|c|}{ 2nd Experiment } \\
\hline $\begin{array}{c}\text { Plus } 0.57 \mu \mathrm{M} \text { IAA } \\
\text { No IAA }\end{array}$ & $\begin{array}{l}\text { last } 15 \text { min collection of the } 120 \text { min preeceding } \\
\text { IAA treatment } \\
\qquad 6 \pm 2 \\
87 \pm 2\end{array}$ & $\begin{array}{l}250 \pm 6 \\
91 \pm 3\end{array}$ \\
\hline
\end{tabular}


amount of accumulated auxin. The same fusiform cells of the stem cambial region arranged in a single layer of the radial rows of cambial derivatives were both, the recipients of molecules of the synthetic growth regulators and the responders by a change in the basipetal efflux of natural auxin. For each $2 \mathrm{x}$ $2 \times 2 \mathrm{~mm}$ receiver block of agar tested directly by a single oat coleoptile, there were 58 such radial rows or about 800 fusiform cells of the stem cambial region. The amounts of natural auxin collected into the agar blocks applied simultaneously to apical and basal ends of the pine stem sections are $1: 3$, respectively (Alina B. Wodzicki et al. 1997). Using these data it is possible to estimate the average contribution to the basipetal efflux (an active polar transport) of a single fusiform cell in the cambial region of the analogous pine trees tested in the experiments presented in this paper. It is equivalent to $0.6 \mathrm{pg}$. of authentic IAA, when calculated for the amount of natural auxin basipetal efflux during first $10 \mathrm{~min}$ of the experiment (using the data summarised in Table 4).

Results of the experiments confirmed the hypothesis that the cambial cells respond to a rise in IAA concentration in the apoplastic space around their apical ends by increasing the basipetal efflux of endogenous auxin. There was no stimulation of the basipetal transport of the exogenous radioactive IAA by the unlabelled auxin when applied to the apical ends of the experimental stem sections during first 45 min in a way analogous to the stimulation of the natural auxin additional efflux. Assuming that all radioactivty collected in the basal receivers was the labelled IAA, the rate of basipetal transport of the exogenous IAA was 0.08 to $0.3 \%$ of the amount absorbed during $60 \mathrm{~min}$. Thus the expected translocation of the unlabelled synthetic IAA at $0.57 \mu \mathrm{M}$ applied at the apical end of 6-mm high stem sections to the single agar-basal-receiver block (calculated using results of the bioassays presented in Table 3 and 4) would be no more than $0.7087 \mathrm{pg}$. These results exclude the possibility that the response of cambial cells to an increase in auxin concentration in the apoplast which stimulated the basipetal efflux of auxin was simply due to the accelerated (or facilitated) flow of the supplied exogenous IAA. The response, which occurred only when the auxin was applied to the apical end of stem sections, suggests effects associated with expression of cell polarity with respect to auxin transport. The oscillations of cell polarity expression recorded when the auxin waves in the pine stem cambial region were studied (Wodzicki et al. 1984) could result from successive increases and decreases in auxin concentration. In intact stem tissues, natural auxin signal propagation could be a chain of reactions between the series of axially neighbouring cells each capable of responding and contributing to the change in auxin concentration in the apoplast which requires only transduction of the received auxin signal by each of the cells to the increase of basipetal efflux of their own auxin. The hypothetical action of such mechanism as conjugated with the necessary feedback inhibition of the processes contributing to the increased polar auxin transport was discussed earlier (Wodzicki 1993). Results of present experiments also seem to provide information concerning possible mechanisms for the IAA signal transduction inducing the increase of basipetal auxin efflux. These are: 1) an increase in the cell membrane proteinaceous complex activity, i.e., the efflux carrier responsible for efficiency of the auxin polar transport; 2) an auxin release from the cellular pool of its conjugates; 3) an increase in the cellular potential for de novo auxin synthesis.

The experiments with the inhibitors of auxin efflux carrier suggest that the IAA signal transduction into the additional natural auxin basipetal efflux from the pine stem cambial region is probably not mediated by the control of auxin binding protein associated with its polar transport at the cell membrane. The processes seem probably not (or at least not directly) to be mediated by the Ca-calmodulin complex involved in regulatory mechanisms dependent upon the cytosolic calcium ion concentration. The hypothetical cellular pool of auxin conjugates, which could be a source of the natural auxin released directly for basipetal export in response to the signalling increase of auxin concentration in an external space around the apical end of the cell as suggested by Wodzicki (1993) has yet to be found.

The results of the experiments in which the auxin basipetal efflux increased significantly within 45 min immediately following the period when it had been strongly reduced by successive collections to agar receivers replaced several times at the basal end of stem sections, suggests supply of new auxin from the synthetic pathway. Thus, transduction of the auxin signalling effect which results in the additional basipetal efflux of auxin by a mechanism stimulating auxin synthesis is quite possible. How the stimulation of new auxin synthesis could be combined with directing this auxin to basipetal efflux would be the next question.

\section{ACKNOWLEDGEMENTS}

The authors wish to thank Dr. Lucy G. Andrews for critical reading of the paper befor submission to the journal.

\section{LITERATURE CITED}

ALDEN T.L. AND ELIASSON L. 1970. Occurence of indole-3-acetic acid in buds of Pinus sylvestris. Physiol. Plant. 23: 145-153.

FUNKE H. 1939. Über den nachweiss kleines wuchstoffmengen. Jahrb. Wiss. Bot.88: 375-378.

GOLDSMITH M.H.M. 1977. The polar transport of auxin. Ann. Rev. Plant Physiol. 28: 439-478.

HERTEL R. 1987. Auxin transport: binding of auxins and phytotropins to the carriers. Accumulation into and efflux from membrane vesicles. In: Plant hormone receptors. (ed. D. Klambt). NATO ASI Series, vol. H10. Springer-Verlag Berlin, Heidelberg, pp 81-92.

HIDAKA H., SASAKI Y., TANAKA T. ENDO T., OHNO S., FUJI Y. AND NAGATA T. 1981. N-(6-aminohexyl)-5-chloro-1-naphtalenesulfonamide, a calmodulin antagonist, inhibits cell proliferation. Proc. Natl. Acad. Sci. USA, 78: 4354-4357.

NIX L.E. AND WODZICKI T.J. 1974. The radial distribution and metabolism of IAA- ${ }^{14} \mathrm{C}$ in Pinus echinata stems in relation to wood formation. Can. J. Bot. 52: 1349-1355.

SANDBERG G., ANDERSON B. AND DUNBERG A. 1981. Identification of 3-indole-acetic acid in Pinus silvestris L. by gas-chromatography-mass spectrometry, and quantitative analysis by ion-pair reversed-phase liquid chromatography with spectrofluorimetric detection. J. Chromatography. 205: 125-137.

THOMSON R.M., HERTEL R., MULLER S. AND TAVARES J.E. 1973. 1-N-Naphtylphthalamic acid and 2.3,5-triiodobenzoic acid in vitro binding to particulate cell fractions and action on auxin transport in corn coleoptile. Planta 109: 337-352.

WENT F.W. AND THIMANN K.V. 1937. Phytohormones. New York. McMillan.

WODZICKI A. B., GESSEL S. AND WODZICKI T.J. 1997. Bioassay for investigation of auxin transport in single cell layers. Acta Soc. Bot. Pol. 66: 355-364.

WODZICKI T.J. 1968. On the question of occurence of indole-3-acetic acid in Pinus silvestris L. Am. J. Bot. 55: 564-571.

WODZICKI T.J. 1993. Auxin apical control of the auxin polar transport and its oscilation - a suggested cellular transduction mechanism. Acta Soc. Bot. Pol. 62: 37-41. 
WODZICKI T.J. AND WODZICKI A.B. 1981. Modulation of the oscillatory system involved in polar transport of auxin by other phytohormones. Physiol. Plant. 53: 176-180.

WODZICKI T.J. AND ZAJACZKOWSKI S. 1989. Auxin waves in cambium and morphogenetic information in plants. In (Proc. 14th Bioch. Congress Pague Coll. Signals in plant development, pp. 4564. (ed. J. Krekule and F. Seidlova, SPB Academic Publishing bv. The Hague, The Nederlands.

WODZICKI T.J., WODZICKI A.B. AND ZAJĄCZKOWSKI S. 1979. Hormonal modulation of the oscillatory system involved in polar transport of auxin. Physiol. Plant. 46: 97-100.
WODZICKI T.J., WODZICKI A.B. AND BROWN C.L. 1984 Oscillation of stem polarity expression in transport of natural auxin of pine cambium. Acta Soc. Bot. Pol. 57: 165-176.

WODZICKI T.J., ABE H., WODZICKI A.B., PHARIS R.P. AND COHEN J.D. 1987. Investigation on the nature of the auxin-wave in the cambial region of pine stem. Plant Physiol. 84: 135-143.

ZAJACZKOWSKI S. AND WODZICKI T.J. 1978. Auxin and plant morphogenesis - a model of regulation. Acta Soc. Bot. Pol. 47: 233-243.

ZAJACZZKOWSKI S., WODZICKI T.J. AND ROMBERGER J.A. 1984. Auxin waves and plant morphogenesis. In: Encyclopedia of Plant Physiology, New Series, Vol. 10 pp 244-262. (ed. T.K. Scott. Springer-Verlag, Berlin, Heidelberg, New York, Tokyo).

\title{
TRANSDUKCJA SYGNAŁU AUKSYNOWEGO \\ W ILOŚCIOWA ZMIANE POLARNEGO TRANSPORTU NATURALNEJ AUKSYNY W KAMBIUM SOSNY
}

\begin{abstract}
STRESZCZENIE
Wyniki doświadczeń z małymi wycinkami pnia Pinus sylvestris L. potwierdziły hipotezę, że komórki rejonu kambialnego reagują zwiększeniem bazypetalnego wypływu naturalnej auksyny w odpowiedzi na podwyższenie stężenia IAA $\mathrm{w}$ apoplaście przy ich apikalnym końcu. Badane wycinki miały rozmiar $6 \mathrm{~mm}$ w kierunku osi, 2-3 mm w kierunku promienia i 6 lub $22 \mathrm{~mm}$ w kierunku równoległym do obwodu pnia drzewa. Przy wysokości $6 \mathrm{~mm}$ wycinki takie obejmują w 90-ciu procentach tylko jeden szereg nieprzeciętych (żywych) komórek wrzecionowatych rejonu kambialnego. Tak więc, przekazywanie sygnału w postaci podwyższonego stężenia auksyny w układzie ponadkomórkowym rejonu kambialnego może mieć charakter reakcji łańcuchowej. Składają się na nią indywidualne reakcje sąsiednich komórek wrzecionowatych, z których każda zdolna jest do przyjęcia sygnały auksynowego $\mathrm{z}$ apoplastu jak też wygenerowania sygnału bazypetalnie przez zwiększenie polarnego wypływu własnej auksyny do apoplastu w sąsiedztwie apikalnej części najbliższych komórek. Szybkość przekazywania sygnału auksynowego w przestrzeni wielokomórkowej przy udziale takiego procesu nie jest ograniczona tempem transportu molekularnego, a jeśli proces ten realizuje się w systemie sprzężeń zwrotnych generuje oscylacje, których rezultatem może być propagacja ponadkomórkowych fal auksynowych.

Wyniki badań z zastosowaniem NPA i TIBA (inhibitorów plazmolemalnego białka, ktorego funkcją jest eksport auksyny z komórki) wykazały, że transdukcja sygnału auksynowego w stymulację bazypetalnego wypływu tego fitohormonu nie jest prawdopodobnie związana z regulacją procesu przenoszenia molekół auksyny poprzez błonę komórkową. Jest więc zapewne procesem wenątrz komórkowym, nie związanym jednak bezpośrednio z regulacją zależną od kompleksu kalmodulina-wapń. Rezultatem doświadczeń, w których podjęto próbę wyczerpania rezerw endogennej auksyny przez wielokrotną zmianę pasków agaru przy końcu bazalnym 6-mm wycinków pnia i zbadania wpływu tego wyczerpania na stymulację bazypetalnego wypływu tego fitohormonu przez apikalne dostarczenie IAA, zdają się wskazywać na udział mechanizmu regulacji syntezy nowej auksyny. Nie wyklucza to możliwości udziału także systemu uwalniania auksyny do bazypetalnego transportu z niezidentyfikowanych jak dotąd cytoplazmatycznych rezerw auksyny w postaci związków lub form uniemożliwiającej jej eksport.
\end{abstract}

SŁOWA KLUCZOWE: sygnał auksynowy, polarny transport, kambium, Pinus sylvestris. 